\title{
KARAKTERISTIK, KESESUAIAN, DAN PENGELOLAAN LAHAN UNTUK BUDIDAYA DI TAMBAK KABUPATEN POHUWATO PROVINSI GORONTALO
}

\author{
Akhmad Mustafa*), Hasnawi*), Admi Athirah*), Abbas Sommeng**), dan \\ Syamsu Alam Ali**) \\ *) Balai Penelitian dan Pengembangan Budidaya Air Payau \\ Jl. Makmur Dg. Sitakka No. 129, Maros 90512, Sulawesi Selatan \\ E-mail: akhmadmustafa@yahoo.com \\ **) Dinas Kelautan dan Perikanan Kabupaten Muna \\ Jl. Pendidikan, Raha, Muna 93613, Sulawesi Tenggara \\ ***) Fakultas IImu Kelautan dan Perikanan, Universitas Hasanuddin \\ Jl. Perintis Kemerdekaan km. 10, Makassar 90245, Sulawesi Selatan
}

(Naskah diterima: 12 September 2013; Disetujui publikasi: 26 Maret 2014)

\begin{abstract}
ABSTRAK
Kabupaten Pohuwato di Provinsi Gorontalo telah ditetapkan sebagai salah satu kabupaten/ kota untuk lokasi pengembangan Kawasan Minapolitan di Indonesia, namun produktivitas tambaknya masih tergolong relatif rendah. Oleh karena itu, dilakukan penelitian untuk mengetahui karakteristik lahan dalam upaya menentukan kesesuaian dan pengelolaan lahan untuk budidaya di tambak demi peningkatan produktivitas tambak, serta penentuan Rencana Tata Ruang Wilayah di Kabupaten Pohuwato. Faktor yang dipertimbangkan dalam mengetahui karakteristik lahan adalah: topografi, tanah, hidrologi, dan iklim. Analisis spasial dalam Sistem Informasi Geografis digunakan dalam penentuan kesesuaian Iahan untuk budidaya tambak. Pengelolaan lahan ditentukan berdasarkan karakteristik lahan yang disesuaikan dengan teknologi dan komoditas yang dapat diaplikasikan di tambak. Hasil penelitian menunjukkan bahwa karakteristik lahan tambak di Kabupaten Pohuwato ditunjukkan oleh topografi yang bentuk wilayahnya relatif datar dan berelevasi rendah, tanah didominasi oleh tanah sulfat masam, kualitas air maupun pasang surut dapat mendukung usaha budidaya di tambak, dan curah hujan tergolong rendah. Dari luas tambak yang ada di Kabupaten Pohuwato yaitu $5.368,2$ ha ternyata $1.954,4$ ha tergolong cukup sesuai (Kelas S2), 2.556,2 ha tergolong kurang sesuai (Kelas S3), dan 857,6 ha tergolong tidak sesuai (Kelas N). Sebagai faktor pembatas budidaya di tambak adalah kemasaman tanah yang tinggi, kandungan bahan organik tanah yang tinggi, dan tekstur yang tergolong kasar, sehingga pengelolaan lahan yang dilakukan adalah remediasi untuk menurunkan kemasaman tanah, pemberian pupuk yang mengandung nitrogen untuk mempercepat proses penguraian bahan organik dan pemberian pupuk kandang untuk lokasi yang rendah kandungan bahan organiknya untuk memperbaiki struktur tanah dasar tambak. Sistem dan teknologi budidaya yang disarankan adalah monokultur udang dengan teknologi tradisional dan tradisional plus untuk tambak yang tergolong cukup sesuai (Kelas S2) dan monokultur ikan bandeng atau polikultur ikan bandeng dan rumput laut dengan teknologi tradisional untuk tambak yang tergolong kurang sesuai (Kelas S3).
\end{abstract}

KATA KUNCI: karakteristik, kesesuaian, pengelolaan, tambak, Kabupaten Pohu wato 
ABSTRACT: Characteristics, suitability, and management of brackishwater ponds land in Pohuwato Regency Gorontalo Province. By: Akhmad Mustafa, Hasnawi, Admi Athirah, Abbas Sommeng, and Syamsu Alam Ali

Pohuwato Regency in Gorontalo Province has been assigned to become one location for Minapolitan Area development in Indonesia, however, the productivity is still considered low. Therefore, a research for determining land characteristics, land suitability, and land management of brackishwater pond is needed, in order to increase productivity and to determine Urban Land Use Plan. Factors considered to be important in determining land characteristics are: topography, soil, hydrology, and climate. Spatial analysis in Geographycal Information System was used in determining land suitability for brackishwater pond. Land management is determined based on land characteristics which should be in line with technology and commodity applied in the brackishwater pond. Research results showed that the land characteristics in Pohuwato Regency is even topography, low elevation, soil dominated by acid sulfate soil, supporting water quality and tides, and low rainfall. From brackishwater pond area of 4,508.7 ha in Pohuwato Regency, there are 1,954.4 ha which is considered moderately suitable (S2 Class), 2,556.2 ha which is considered marginally suitable (S3 Class), and 857.64 ha which is not suitable (N Class). The limiting factors in brackishwater pond are high soil acidity, high organic content, and coarse soil texture. Therefore, to overcome these factors, it is required to decrease soil acidity with remediation, to apply nitrogen fertilizers in order to breakdown organic content, and to apply organic fertilizers to improve soil structure in area with low organic matter content. It is recommended to apply monoculture system to grow shrimps with traditional and traditional-plus technologies, for the moderately suitable ponds (S2 Class), and to apply monoculture system to grow milkfish or polyculture system to grow milkfish and seaweed with traditional technology for the marginally suitable ponds (S3 Class).

KEYWORDS: characteristics, suitability, management, brackishwater pond, Pohuwato Regency

\section{PENDAHULUAN}

Kementerian Kelautan dan Perikanan (KKP) telah memfokuskan untuk menggenjot produksi perikanan budidaya dan mengendalikan perikanan tangkap. Oleh karena itu, peluang sekaligus tumpuan besar akan tertuju pada perikanan budidaya atau akuakultur. Budidaya di tambak merupakan industri akuakultur terbesar di Indonesia yang sangat diharapkan menjadi andalan dalam mewujudkan visi: Indonesia penghasil produk kelautan dan perikanan terbesar 2015, serta misi: menyejahterakan masyarakat kelautan dan perikanan. Dari berbagai komoditas perikanan budidaya di tambak, KKP telah menentukan komoditas unggulan, di antaranya udang windu (Penaeus monodon), udang vaname (Litopenaeus vannamei), ikan bandeng (Chanos chanos), dan rumput laut (Gracilaria verrucosa).

Semua jenis komoditas termasuk komoditas perikanan budidaya di tambak yang ber- basis lahan, agar dapat tumbuh atau hidup dan berproduksi memerlukan persyaratanpersyaratan lahan tertentu yang dapat berbeda satu sama lain. Dalam kaitannya dengan sumberdaya alam, dikenal istilah lahan yang merupakan suatu lingkungan fisik yang terdiri atas tanah, topografi, hidrologi, vegetasi, dan iklim di mana pada batas- batas tertentu memengaruhi kemampuan penggunaan lahan (Mustafa et al., 2011). Oleh karena itu, perbedaan kombinasi penyusun lingkungan fisik lahan tersebut akan memberikan karakteristik lahan yang berbeda dan pada akhirnya kesesuaian dan pengelolaan lahan yang berbeda pula.

Evaluasi kesesuaian lahan sangat penting dilakukan karena lahan memiliki sifat fisik, sosial, ekonomi, dan geografi yang bervariasi atau lahan diciptakan tidak sama (Rossiter, 1996). Evaluasi kesesuaian Iahan merupakan suatu proses pendugaan keragaan lahan apabila lahan digunakan untuk tujuan tertentu (FAO, 1985) atau sebagai metode yang men- 
jelaskan atau memprediksi kegunaan potensial dari lahan (van Dieven et al., 1991), serta bertujuan untuk menyelamatkan sumberdaya yang ada secara berkelanjutan (Young, 1987). Kesesuaian Iahan merupakan suatu kunci sukses dalam kegiatan akuakultur yang memengaruhi kesuksesan dan keberlanjutannya, serta dapat memecahkan konflik antara berbagai kegiatan dan membuat penggunaan lahan lebih rasional (Pérez et al., 2003; Hossain \& Das, 2010). Dari evaluasi kesesuaian Iahan dapat memberikan efisiensi dan keserasian lingkungan yang paling maksimum, setelah memperhatikan benturan kepentingan dari berbagai pihak. Manfaat yang mendasar dari evaluasi kesesuaian lahan yaitu untuk menilai kesesuaian untuk penggunaan tertentu dan memprediksi risiko yang dapat terjadi, serta mengetahui faktor pembatas terhadap lahan terlebih dahulu sebelum digunakan. Salah satu kebijakan yang bersifat mengarahkan adalah mendorong masyarakat berbudidaya sesuai dengan kesesuaian lahan.

Pengelolaan lahan yang tepat dapat meningkatkan produktivitas lahan termasuk lahan budidaya di tambak dengan penggunaan masukan yang seminimum mungkin dan tidak menyebabkan terjadinya degradasi lingkungan. Pengelolaan tambak termasuk pengeIolaan lahannya merupakan faktor penting setelah penentuan kesesuaian lahan budidaya di tambak dalam rangka pengembangan ilmu pengetahuan dan budidaya di tambak yang berkelanjutan (Karthik et al., 2005). Secara umum, tambak dijumpai di kawasan lahan rawa karena pada kawasan tersebut tersedia sumberdaya alam yang dapat dimanfaatkan untuk budidaya di tambak. Tiga jenis tanah yang dijumpai di kawasan lahan rawa yaitu: tanah sulfat masam, tanah gambut, dan tanah aluvial non- sulfat masam termasuk tanah salin (Mustafa, 2011). Setiap jenis tanah memiliki karakteristik tersendiri sehingga pengelolaan lahannya juga bersifat khas terhadap penggunaan lahan tersebut (Mustafa \& Rachmansyah, 2008).

Berdasarkan Keputusan Menteri Kelautan dan Perikanan Republik Indonesia No. KEP.32/ MEN/2010 tentang Penetapan Kawasan Minapolitan maka Kabupaten Pohuwato telah ditetapkan sebagai lokasi pengembangan Kawasan Minapolitan di Indonesia. Kabupaten Pohuwato merupakan daerah pesisir di Provinsi Gorontalo yang masuk dalam kawasan pengelolaan Teluk Tomini. Kabupaten
Pohuwato memiliki lahan tambak yang cukup luas yaitu 3.284 ha dengan produksi 1.534,60 ton (DKP Kabupaten Pohuwato, 2010). Hal ini mengindikasikan bahwa tambak di Kabupaten Pohuwatu tergolong memiliki produktivitas yang relatif rendah. Oleh karena itu, dilakukan penelitian yang bertujuan untuk mengetahui karakteristik lahan untuk menentukan kesesuaian dan pengelolaan lahan agar produktivitas tambak dapat meningkat dan berkelanjutan, serta dapat menjadi acuan Pemerintah Kabupaten Pohuwato secara khusus dan Pemerintah Provinsi Gorontalo secara umum dalam penentuan Rencana Tata Ruang Wilayah.

\section{BAHAN DAN METODE}

\section{Lokasi dan Waktu Penelitian}

Penelitian dilaksanakan di wilayah pesisir Kabupaten Pohuwato yaitu di Kecamatan Paguat, Marisa, Duhiadaa, Patilanggio, Randangan, Wanggarasi, Lemito, Popayato Barat, Popayato, dan Popayato Timur. Penelitian di lapangan dilaksanakan pada bulan Mei 2011 dan analisis kualitas tanah dan air berturut- turut dilaksanakan di Laboratorium Tanah dan Air Balai Penelitian dan Pengembangan Budidaya Air Payau di Maros pada bulan Juni sampai September 2011.

\section{Pengumpulan Data}

Penelitian diawali berupa diskusi dengan Sekretaris dan Staf Dinas Kelautan dan Perikanan Kabupaten Pohuwato di Marisa untuk mendapatkan gambaran umum budidaya di tambak Kabupaten Pohuwato.

\section{Data Primer}

Data primer yang dikumpulkan meliputi data karakteristik lahan yaitu: tanah, topografi, dan hidrologi. Penentuan titik- titik pengambilan contoh tanah didasarkan pada peta satuan unit. Pengambilan contoh tanah dan air dilakukan pada 75 titik di lokasi pertambakan dan 15 titik untuk contoh air laut. Peubah kualitas tanah yang diukur langsung di lapangan adalah $\mathrm{pH}_{\mathrm{F}}(\mathrm{pH}$ tanah yang diukur di lapangan) dengan $\mathrm{pH}$ - meter dan $\mathrm{pH}_{\mathrm{FOx}}(\mathrm{pH}$ tanah yang diukur di lapangan setelah dioksidasi dengan hidrogen peroksida $\left(\mathrm{H}_{2} \mathrm{O}_{2}\right)$ $30 \%$ dengan $\mathrm{pH}$ - meter (Ahern \& Rayment, 1998). Contoh tanah diambil pada dua kedalaman tanah yaitu 0- 0,2 dan 0,5-0,7 m dari 
permukaan tanah. Contoh tanah di- oven- kan pada suhu $80^{\circ} \mathrm{C}-85^{\circ} \mathrm{C}$ selama 48 jam (Ahern \& Blunden, 1998). Kualitas tanah yang dianalisis di laboratorium meliputi $S_{p}$ (sulfur peroksida), $\mathrm{S}_{\mathrm{KCl}}$ (sulfur yang diekstrak dengan $\mathrm{KCl}$ ), $\mathrm{S}_{\mathrm{POS}}$ $\left(\mathrm{S}_{\mathrm{P}}-\mathrm{S}_{\mathrm{KCl}}\right.$ ), TPA (Titratable Peroxide Acidity), TAA (Titratable Actual Acidity), TSA (Titratable Sulfidic Acidity) (TPA-TAA), FeS $_{2}$, C- organik dengan metode Walkley dan Black, N-total dengan meto de Kjedhal, $\mathrm{PO}_{4}$ dengan meto de Bray 1 atau Olsen, Fe dengan spektrofotometer, Al dengan spektrofotometer, dan tekstur dengan metode hidrometer (Ahern et al., 1998a, 1998b; Ahern \& McElnea, 2004; McElnea \& Ahern, 2004a; 2004b; 2004c; 2004d; Sulaeman et al., 2005; Agus et al., 2006).

Peubah kualitas air yang diukur langsung di lapangan adalah suhu, salinitas, oksigen terlarut, dan $\mathrm{pH}$ dengan menggunakan Hydrolab ${ }^{\circledR}$ Minisonde. Contoh air untuk analisis di laboratorium diambil dengan menggunakan Kmerer Water Sampler dan dipreservasi mengikuti petunjuk APHA (2005). Peubah kualitas air yang dianalisis di laboratorium meliputi: $\mathrm{NO}_{3}, \mathrm{NO}_{2}, \mathrm{NH}_{3}$, dan $\mathrm{PO}_{4}$ berdasarkan petunjuk Parsons et al. (1989) dan APHA (2005).

Topografi diketahui melalui pengamatan di lapangan. Data hidrologi diketahui dari pasang surut dan kualitas air. Pengukuran pasang surut dilakukan di salah satu titik pengamatan yang terletak di kawasan pesisir Kecamatan Marisa. Pengukuran pasang surut dilakukan dengan interval satu jam selama 39 jam, dengan menggunakan palem atau rambu pengamat pasang surut. Hasil pengukuran pasang surut dikoreksi dengan data pasang surut dari Dinas Hidro-Oseanografi pada stasiun terdekat yaitu: Moutong (Kabupaten Parigi Moutong, Provinsi Sulawesi Tengah). Seluruh titik- titik pengambilan contoh ditentukan titik koordinatnya dengan menggunakan GPS (Global Positioning System).

\section{Data Sekunder}

Data sekunder termasuk data iklim dikumpulkan melalui penelusuran berbagai laporan, pustaka, dan hasil penelitian dari berbagai instansi terkait. Peta yang dikumpulkan antara lain peta Rupabumi Indonesia skala 1:50.000 dengan nomor lembar 2216- 13 (Litokuntadaa), 2216- 14 (Marisa), 2216- 23 (Paguat), dan 2216- 41 (Lemito), serta peta Administrasi Kabupaten Pohuwato.

\section{Analisis Data}

Statistik deskriptif digunakan untuk dapat menggambarkan data yang ada secara umum. Peta penutup/ penggunaan lahan yang digunakan berasal dari hasil klasifikasi Citra ALOS (Advanced Land Observing Satellite) AVNIR- 2 (The Advanced Visible and Near Infrared Radiometer type 2) dengan Scene ID ALAV2A212973590 akuisisi 23 Januari 2010 dan ALAV2A217203590 akuisisi 21 Februari 2010 dengan menggunakan Program Er Mapper 7.1 yang diintegrasikan dengan peta dasar dari peta Rupabumi Indonesia.

Informasi spasial lain yang diperoleh dari data primer dan sekunder juga diintegrasikan dengan peta penutup/ penggunaan lahan. Data primer, sekunder, dan peta penutup/ penggunaan lahan yang sudah dikumpulkan, selanjutnya dilakukan pengolahan data dengan menggunakan analisis spasial dalam SIG (Sistem Informasi Geografis). Kriteria yang digunakan dalam penentuan kesesuaian lahan untuk budidaya tambak mengacu pada kriteria yang ada (Mustafa et al., 2007).

Asumsi yang diterapkan dalam evaluasi kesesuaian lahan tambak disesuaikan pada pengelolaan yang rendah atau sederhana. Infrastruktur, aksesibilitas, dan pemasaran hasil produksi tidak dipertimbangkan dalam evaluasi kesesuaian lahan ini. Hasil proses penilaian kesesuaian lahan ditampilkan dalam bentuk sistem klasifikasi kesesuaian lahan aktual. Sistem klasifikasi kesesuaian lahan ditentukan sampai tingkat kategori Kelas. Pengelolaan lahan yang direkomendasikan didasarkan pada karakteristik Iahan dan disesuaikan dengan tingkat teknologi dan komoditas yang diaplikasikan di tambak.

\section{HASIL DAN BAHASAN}

\section{Karakteristik Lahan}

Telah dijelaskan sebelumnya bahwa lahan merupakan suatu lingkungan fisik yang terdiri atas topografi, tanah, hidrologi, vegetasi, dan iklim. Oleh karena itu, setiap bagian dari lahan tersebut, kecuali vegetasi akan dibahas pada bagian berikut.

\section{Topografi}

Topografi yang dipertimbangkan dalam evaluasi kesesuaian lahan adalah bentuk wilayah (relief) atau lereng dan ketinggian tempat di atas permukaan laut. Tambak di 
Kabupaten Pohuwato umumnya dibangun pada areal yang sebelumnya adalah kawasan mangrove. Secara umum kawasan mangrove berada pada topografi yang relatif datar dan elevasi yang rendah sehingga dapat dijangkau oleh pasang surut agar mangrove dapat hidup dan berkembang. Dengan demikian, topografi kawasan tambak di Kabupaten Pohuwato tergolong datar dan rendah. Lahan yang baik untuk budidaya di tambak adalah relatif datar (Chanratchakool et al., 1995). Dalam hal ini, dengan elevasi tambak yang tepat maka pemasukan dan pembuangan air tambak dapat dilakukan secara gravitasi. Lokasi tambak sebaiknya yang mempunyai elevasi tertentu agar memudahkan pengelolaan air, sehingga tambak cukup mendapatkan air pada saat terjadi pasang harian dan dapat dikeringkan pada saat surut harian (Poernomo, 1988). Menurut Bose et al. (1991), elevasi dasar tambak yang ideal adalah apabila dasar tambak dapat dikeringkan kapan saja dan dapat diisi air secara gravitasi selama lima hari dari setiap siklus pasang surut.

\section{Tanah}

Jenis tanah yang dijumpai di kawasan pertambakan Kabupaten Pohuwato didominasi tanah sulfat masam dan sebagian kecil tanah sulfat masam yang berasosiasi dengan tanah gambut. Oleh karena itu, peubah kualitas tanah yang dianalisis adalah peubah kualitas tanah yang khas atau menjadi ciri spesifik untuk tanah sulfat masam. $\mathrm{pH}_{\mathrm{F}}$ tanah relatif sama pada kedalaman tanah yang berbeda, sedangkan $\mathrm{pH}_{\text {FOx }}$ lebih tinggi pada kedalaman 0-0,25 m daripada kedalaman 0,50-0,75 m (Tabel 1). Sebagai akibat $\mathrm{pH}_{\mathrm{F}}$ yang relatif sama dan $\mathrm{pH}_{\mathrm{FOX}}$ yang lebih tinggi pada kedalaman 0-0,25 m; mengakibatkan $\mathrm{pH}_{\mathrm{F}}-\mathrm{pH}_{\mathrm{FOx}}$ lebih rendah pada kedalaman $0-0,25 \mathrm{~m}$ yang berarti potensi kemasaman pada kedalaman 0-0,25 m lebih rendah daripada kedalaman 0,50-0,75 m. Rendahnya potensi kemasaman pada kedalaman 0-0,25 m sebagai akibat proses remediasi yang berjalan secara alami untuk waktu yang cukup lama yang menyebabkan berkurangnya unsur atau senyawa penyebab kemasaman. Potensi kemasaman yang rendah pada kedalaman 0- 0,25 m juga diduga sebagai akibat pemberian kapur oleh pembudidaya tambak pada setiap persiapan tambak yang hanya dapat bereaksi pada kedalaman kurang dari 0,1 m. Telah dilaporkan bahwa kapur yang diberikan hanya memberikan pengaruh yang nyata sampai kedalaman 0,05 m (Boyd, 1995).
Tanah sulfat masam dicirikan dengan kandungan $\mathrm{FeS}_{2}$ (pirit), maka salah satu sumber kemasamannya adalah S (sulfur). Pirit yang teroksidasi akan menghasilkan asam sulfat dan ferrosulfat yang apabila bereaksi dengan air melepaskan ferrisulfat yang selanjutnya apabila teroksidasi kembali akan menghasilkan asam sulfat. Sebagai sumber kemasaman yang penting pada tanah sulfat masam, maka Syang diukur dalam bentuk $\mathrm{S}_{\mathrm{POS}}$ tanah telah digunakan oleh Ahern et al. (1998b) untuk menentukan kebutuhan kapur bagi tanah sulfat masam. Tabel 1 menunjukkan bahwa kandungan $\mathrm{S}_{\mathrm{pos}}$ tanah yang tidak terlalu tinggi jika dibandingkan dengan tanah sulfat masam dari tambak di pantai Timur Sulawesi Selatan seperti telah dilaporkan oleh Mustafa et al. (2011). Hal ini berarti bahwa kapur yang dibutuhkan juga tidak terlalu tinggi di tambak Kabupaten Pohuwato. Tanah sulfat masam juga ditandai keberadaan unsur beracun seperti Fe (besi) dan Al (aluminium) di tambak Kabupaten Pohuwato. Pada tanah sulfat masam, Fe, dan Al adalah logam yang melimpah, di mana Fe merupakan produk langsung dari oksidasi FeS, dan Al merupakan produksi langsung dari pelapukan alumino- silikat oleh kemasaman (Golez \& Kyuma, 1997). Kandungan Fe dan Al ini dapat menyebabkan kandungan $\mathrm{PO}_{4}$ (fosfat) tanah relatif lebih rendah. Hal ini sebagai akibat dari Fe dan Al tanah yang dapat menyebabkan $\mathrm{PO}_{4}$ menjadi tidak tersedia. Pada tanah yang $\mathrm{pH}$ - nya rendah, $\mathrm{PO}_{4}$ diikat secara kuat oleh $\mathrm{Fe}$ dan Al dalam bentuk $\mathrm{FePO}_{4}$ atau $\mathrm{AlPO}_{4}$ yang tidak larut (Mustafa $\&$ Sammut, 2007). Secara umum, kandungan $\mathrm{PO}_{4}$ tanah tambak di Kabupaten Pohuwato hanya tergolong cukup sesuai untuk budidaya di tambak. Kandungan $\mathrm{PO}_{4}$ lebih dari $60 \mathrm{mg} / \mathrm{L}$ dalam tanah tambak dapat digolongkan sebagai slight atau tergolong baik dengan faktor pembatas yang sangat mudah diatasi (Karthik et al., 2005).

Maksimum kandungan C- organik (karbonorganik) tanah pada kedalaman $0-0,25$ m yaitu $16,59 \%$ lebih rendah daripada kedalaman 0,50- 0,75 m yaitu 19,94\%di tambak Kabupaten Pohuwato. Tanah di Kabupaten Pohuwato juga diklasifikasikan dalam Organosol atau tanah gambut. Tanah gambut adalah tanah yang dicirikan dengan kandungan $\mathrm{C}$ - organik yang tinggi yaitu melebihi 15\%(Boyd et al., 2002a). Tanah tambak dengan kandungan $\mathrm{C}$ - organik antara $3,1 \%$ dan $15,0 \%$ tergolong tinggi dan kandungan C- organik antara $1,1 \%$ dan 3,0\% tergolong sangat baik untuk budidaya tambak (Boyd et al., 2002b). 
Tabel 1. Statistik deskriptif kualitas tanah tambak pada kedalaman 0- 0,25 m dan 0,50- 0,75 m di Kabupaten Pohuwato Provinsi Gorontalo $(n=75)$

Table 1. Descriptive statistics of brackishwater pond soil quality at 0-0.25 m and 0.50-0.75 m of depth in Pohuwato Regency Gorontalo Province $(n=75)$

\begin{tabular}{|c|c|c|c|c|}
\hline \multirow[b]{2}{*}{$\begin{array}{l}\text { Peubah } \\
\text { Variable }\end{array}$} & \multicolumn{2}{|c|}{$\begin{array}{l}\text { Kedalaman } 0-0,25 \mathrm{~m} \\
\text { Depth of } 0-0.25 \mathrm{~m}\end{array}$} & \multicolumn{2}{|c|}{$\begin{array}{l}\text { Kedalaman } 0,50-0,75 \mathrm{~m} \\
\text { Depth of } 0.50-0.75 \mathrm{~m}\end{array}$} \\
\hline & $\begin{array}{l}\text { Kisaran } \\
\text { Range }\end{array}$ & $\begin{array}{c}\text { Rataan } \pm \text { Standar } \\
\text { deviasi } \\
\text { Average } \pm \text { Standard } \\
\text { deviation }\end{array}$ & $\begin{array}{l}\text { Kisaran } \\
\text { Range }\end{array}$ & $\begin{array}{c}\text { Rataan } \pm \text { Standar } \\
\text { deviasi } \\
\text { Average } \pm \text { Standard } \\
\text { deviation }\end{array}$ \\
\hline $\mathrm{pH}_{\mathrm{F}}$ & $6.06-7.53$ & $6.92 \pm 0.26$ & $5.47-6.86$ & $6.86 \pm 0.28$ \\
\hline $\mathrm{pH}_{\mathrm{FOX}}$ & $0.95-7.78$ & $3.84+2.29$ & $0.87-2.95$ & $2.95 \pm 2.20$ \\
\hline $\mathrm{pH}_{\mathrm{F}}-\mathrm{pH}_{\mathrm{FOX}}$ & $-0.96-6.26$ & $3.08 \pm 2.25$ & $-0.83-3.90$ & $3.90 \pm 2.24$ \\
\hline $\begin{array}{l}\text { TPA (mol H } \pm / \text { ton) } \\
\text { TPA (mole } \mathrm{H} \pm / \text { ton) }\end{array}$ & $0.0-1,434.0$ & $432.7 \pm 480.9$ & $0.0-604.2$ & $604.2 \pm 582.5$ \\
\hline $\begin{array}{l}\text { TAA (mol } \mathrm{H} \pm / \text { ton) } \\
\text { TAA (mole } \mathrm{H} \pm \text { ton) }\end{array}$ & $0.0-7.0$ & $0.1 \pm 0.9$ & $0.0-4.4$ & $4.4 \pm 15.9$ \\
\hline $\begin{array}{l}\text { TSA (mol } \mathrm{H} \pm / \text { ton) } \\
\text { TSA (mole } \mathrm{H} \pm / \text { ton) }\end{array}$ & $0.0-1,434.0$ & $432.7 \pm 480.9$ & $0.0-604.1$ & $604.1 \pm 582.4$ \\
\hline $\mathrm{S}_{\mathrm{KCl}}(\%$ & $0.11-1.25$ & $0.39 \pm 0.28$ & $0.10-0.53$ & $0.53 \pm 0.44$ \\
\hline$S_{p}(\%)$ & $0.19-4.38$ & $1.67 \pm 1.35$ & $0.15-2.15$ & $2.15 \pm 1.47$ \\
\hline $\mathrm{S}_{\mathrm{POS}}(\%)$ & $0.09-3.51$ & $1.29 \pm 1.13$ & $0.02-1.61$ & $1.61 \pm 1.14$ \\
\hline $\begin{array}{l}\text { C-organik } \\
\text { Organic-C (\% }\end{array}$ & $0.08-16.59$ & $4.68 \pm 4.64$ & $0.09-4.99$ & $4.99 \pm 4.96$ \\
\hline $\begin{array}{l}\text { N-total } \\
\text { Total-N (\%) }\end{array}$ & $0.03-1.23$ & $0.26 \pm 0.25$ & $0.01-0.18$ & $0.18 \pm 0.17$ \\
\hline $\begin{array}{l}\text { Rasio C:N } \\
\text { C:N ratio }\end{array}$ & $3.33-137.21$ & $19.53 \pm 18.02$ & $1.19-27.79$ & $27.79 \pm 17.60$ \\
\hline $\mathrm{PO}_{4}(\mathrm{mg} / \mathrm{L})$ & $0.01-204.17$ & $54.02 \pm 46.87$ & $0.00-37.58$ & $37.58 \pm 36.36$ \\
\hline $\mathrm{FeS}_{2}(\%)$ & $0.01-6.40$ & $1.93 \pm 2.15$ & $0.01-2.70$ & $2.70 \pm 2.60$ \\
\hline $\mathrm{Fe}(\mathrm{mg} / \mathrm{L})$ & $9.5-4,881.5$ & $2,419.4 \pm 2,058.7$ & $0.1-146.3$ & $146.3 \pm 142.9$ \\
\hline $\mathrm{Al}(\mathrm{mg} / \mathrm{L})$ & $0.1-393.5$ & $103.9 \pm 103.9$ & $0.1-28.09$ & $28.09+27.18$ \\
\hline Liat (Clay) ) (\% & $0-42$ & $9 \pm 12$ & $0-9$ & $9 \pm 12$ \\
\hline Debu (Silt ) (\% & $2-60$ & $32 \pm 13$ & $2-33$ & $33 \pm 14$ \\
\hline Pasir (Sand) $(\%)$ & $40-98$ & $59+14$ & $40-58$ & $58 \pm 15$ \\
\hline $\begin{array}{l}\text { Kelas tekstur } \\
\text { Textural class }\end{array}$ & $\begin{array}{l}\text { Liat (Clay ) } 1 . \\
\text { (Sandy clay ) } \\
\text { berpasir (San } \\
\text { Lempung ber } \\
\text { Lempung ber } \\
\text { 10.29\% Lemp } \\
\text { Lempung ber } \\
45.99 \% \text { Pasir } \\
\text { sand) } 13.24^{\circ}\end{array}$ & $\begin{array}{l}47 \% \text { Liat berpasir } \\
1.47 \% \text { Lempung liat } \\
\text { dy clay loam ) } 7.35 \% \\
\text { liat (Clay loam ) } 5.88 \% \\
\text { debu (Silty loam ) } \\
\text { oung (Loam ) } 11.77 \% \\
\text { pasir (Sandy loam ) } \\
\text { berlempung (Loamy } \\
\$ \text { Pasir (Sand) } 2.94 \%\end{array}$ & $\begin{array}{l}\text { Liat (Clay) } 2 \\
\text { berpasir (Sar } \\
\text { Lempung be } \\
\text { Lempung be } \\
17.65 \% \text { Lem } \\
\text { Lempung be } \\
45.59 \% \text { Pasi } \\
\text { sand) } 10.29\end{array}$ & $\begin{array}{l}94 \% \text { Lempung liat } \\
\text { dy clay loam ) } 4.42 \% \\
\text { rliat (Clay loam ) } 1.47 \% \\
\text { rdebu (Silty loam) } \\
\text { pung (Loam ) } 11.76 \% \\
\text { rpasir (Sandy loam ) } \\
\text { berlempung (Loamy } \\
\% \text { Pasir (Sand) } 5.88 \%\end{array}$ \\
\hline
\end{tabular}


Kebanyakan N (nitrogen) dalam tanah dasar tambak terkandung dalam bahan organik. Bakteri memineralisasi bahan organik menjadi amonia yang dapat dimanfaatkan untuk pertumbuhan makanan alami. Kandungan Ntotal (nitrogen- tanah) tambak di Kabupaten Pohuwato tergolong tidak sesuai sampai sangat sesuai, tetapi secara umum tergolong kurang sesuai untuk budidaya di tambak. Analisis kandungan $\mathrm{N}$ - total tanah dilakukan bukan hanya untuk mengetahui kandungan $\mathrm{N}$ total tanah, tetapi juga untuk mengetahui rasio C:N tanah. Tampaknya, rasio C:N tanah tambak di Kabupaten Pohuwato sangat bervariasi dengan rata- rata 19,53:1 pada kedalaman 0$0,25 \mathrm{~m}$ dan $27,79: 1$ pada kedalaman 0,50-0,75 $\mathrm{m}$. Rasio C:N yang ideal untuk tanah tambak adalah 8:1 sampai 12:1 (Boyd, 2008).

Kandungan fraksi pasir umumnya tinggi (rata- rata lebih dari 55\% dan sebaliknya kandungan liat sangat rendah (rata- rata kurang dari $10 \%$ di tambak Kabupaten Pohuwato. Tekstur tanah lempung berpasir adalah tekstur tanah yang dominan di tambak Kabupaten Pohuwato yaitu dijumpai pada $45,99 \%$ contoh tanah pada kedalaman 0- 0,25 m dan 45,59\% pada kedalaman tanah 0,50-0,75 m. Tekstur tanah yang demikian tergolong tekstur yang kurang menguntungkan secara fisik untuk konstruksi pematang tambak. Secara kimia, tekstur tanah demikian juga tidak mampu menyimpan unsur hara dan memiliki daya sangga tanah yang rendah sehingga fluktuasi $\mathrm{pH}$ tanah dapat lebih besar. Tanah tambak dengan kandungan pasir 5\% 10\% tergolong baik untuk budidaya di tambak. Tekstur tanah yang baik untuk tambak adalah: liat, lempung berliat, lempung liat berdebu, lempung berdebu, lempung, dan lempung liat berpasir (llyas et al., 1987). Dikatakan oleh Boyd (1995) bahwa suatu material tanah yang merupakan campuran dari partikel yang berbeda ukuran dan mengandung minimum 30\% liat adalah ideal untuk konstruksi tambak.

\section{Hidrologi}

Suhu air di tambak Kabupaten Pohuwato memiliki variasi yang cukup besar dengan ratarata $30,09^{\circ} \mathrm{C}$ (Tabel 2). Suhu air yang tinggi terukur pada tambak yang airnya sangat dangkal. Suhu air di laut yang merupakan sumber air bagi tambak memiliki variasi yang relatif kecil dengan rata- rata $30,73^{\circ} \mathrm{C}$. Suhu air yang layak untuk budidaya udang windu berkisar antara $26^{\circ} \mathrm{C}$ dan $32^{\circ} \mathrm{C}$ dan optimumnya antara $29^{\circ} \mathrm{C}$ dan $30^{\circ} \mathrm{C}$ (Poernomo, 1988). Suhu optimum untuk pertumbuhan udang vaname adalah $28^{\circ} \mathrm{C}-30^{\circ} \mathrm{C}$ (Ponce- Palatox et al., 1997). Suhu air yang baik untuk ikan bandeng adalah $27^{\circ} \mathrm{C}-31^{\circ} \mathrm{C}$ (Ismail et al., 1993).

Tabel 2. Statistik deskriptif kualitas air di tambak $(n=75)$ dan laut $(n=15)$ Kabupaten Pohuwato Provinsi Gorontalo

Table2. Descriptive statistics of water quality in brackishwater pond $(n=75)$ and in the sea $(n=15)$ of Pohuwato Regency Gor ontalo Province

\begin{tabular}{|c|c|c|c|c|}
\hline \multirow[b]{2}{*}{$\begin{array}{l}\text { Peubah } \\
\text { Variable }\end{array}$} & \multicolumn{2}{|c|}{ Tambak (Brackishwater pond) } & \multicolumn{2}{|c|}{ Laut (Sea) ) } \\
\hline & $\begin{array}{c}\text { Kisaran } \\
\text { Range }\end{array}$ & $\begin{array}{l}\text { Rataan } \pm \text { Standar } \\
\text { deviasi } \\
\text { Average } \pm \text { Standard } \\
\text { deviation }\end{array}$ & $\begin{array}{c}\text { Kisaran } \\
\text { Range }\end{array}$ & $\begin{array}{c}\text { Rataan } \pm \text { Standar } \\
\text { deviasi } \\
\text { Average } \pm \text { Standard } \\
\text { deviation }\end{array}$ \\
\hline Suhu (Temperature) $\left({ }^{\circ} \mathrm{C}\right)$ & 20.26-37.91 & $33.09 \pm 2.56$ & 30.04-31.66 & $30.73 \pm 0.46$ \\
\hline Salinitas (Salinity ) (ppt) & $6.86-47.11$ & $32.31 \pm 7.62$ & $32.22-33.09$ & $32.72 \pm 0.24$ \\
\hline $\mathrm{pH}$ & 7.49-9.32 & $8.26 \pm 0.44$ & $7.49-8.14$ & $7.96 \pm 0.16$ \\
\hline $\begin{array}{l}\text { Oksigen terlarut } \\
\text { Dissolved oxygen }(\mathrm{mg} / \mathrm{L})\end{array}$ & $4.95-7.66$ & $6.05 \pm 0.53$ & $4.53-6.71$ & $5.18 \pm 0.53$ \\
\hline $\mathrm{NO}_{3}(\mathrm{mg} / \mathrm{L})$ & $0.0289-6.9507$ & $0.3995 \pm 1.0705$ & $0.0815-2.1424$ & $0.4013 \pm 0.5040$ \\
\hline $\mathrm{NO}_{2}(\mathrm{mg} / \mathrm{L})$ & $0.0108-0.6152$ & $0.0277 \pm 0.0753$ & $0.0008-0.0282$ & $0.0105 \pm 0.0097$ \\
\hline $\mathrm{NH}_{3}(\mathrm{mg} / \mathrm{L})$ & $0.0132-3.4924$ & $0.5312 \pm 0.4632$ & $0.0177-0.3218$ & $0.1445 \pm 0.0852$ \\
\hline $\mathrm{PO}_{4}(\mathrm{mg} / \mathrm{L})$ & $0.0030-4.5278$ & $0.2924 \pm 0.6874$ & $0.0060-0.0798$ & $0.0271 \pm 0.0203$ \\
\hline
\end{tabular}


Suhu air $25^{\circ} \mathrm{C}-30^{\circ} \mathrm{C}$ adalah suhu yang baik untuk budidaya rumput laut (Hurtado- Ponce $\&$ Umezaki, 1987).

Kisaran salinitas air di tambak sangat bervariasi dari 6,86 ppt sampai 47,11 ppt dengan rata- rata 32,32 ppt (Tabel 2). Salinitas air yang rendah terukur pada saluran dan sungai yang merupakan sumber air, sedangkan salinitas air yang tinggi terukur pada tambak yang tidak mempunyai sumber air tawar dan tambak yang berada di sekitar tambak garam di Kecamatan Randangan. Salinitas air di laut relatif kecil variasinya dengan nilai rata- rata $32,72 \mathrm{ppt}$ (Tabel 2). Udang windu, udang vaname, ikan bandeng, dan rumput laut merupakan organisme eurihalin, namun karena dibudidayakan untuk tujuan komersial, maka kisaran salinitas yang optimum perlu dipertahankan. Udang windu mampu menyesuaikan diri terhadap salinitas air 3-45 ppt, namun untuk pertumbuhan optimum diperlukan salinitas air 15- 25 ppt (Poernomo, 1988). Udang vaname umumnya tumbuh optimum pada salinitas air 15- 20 ppt (Bray et al., 1994). Ikan bandeng dapat tumbuh optimum pada salinitas air 15- 30 ppt (Ismail et al., 1993). Salinitas air optimum untuk rumput laut adalah $15 \mathrm{ppt}$ sampai $25 \mathrm{ppt}$ (Anonymous, 1991) dan 25,6 ppt pada tambak tanah sulfat masam di pantai Timur Sulawesi Selatan (Mustafa et al., 2007).

Kisaran $\mathrm{pH}$ yang baik untuk udang windu adalah 7,5-8,7 dengan optimum 8,0-8,5 (Poernomo, 1988). Ikan bandeng tumbuh dengan optimum pada pH air 7,0- 8,5 (Ismail et al., 1993). Menurut Swingle (1968), pada umumnya $\mathrm{pH}$ air yang baik bagi organisme akuatik adalah 6,5-9,0; pada pH 9,5-11,0 dan 4,0-6,0 mengakibatkan produksi rendah dan jika lebih rendah dari 4,0 atau lebih tinggi 11,0 akan meracuni ikan. Kisaran $\mathrm{pH}$ air pada tambak di Kabupaten Pohuwato adalah 7,49- 9,32 dengan rata- rata 8,26 dan $\mathrm{pH}$ air di laut adalah 7,498,14 dengan rata- rata 7,96 yang menunjukkan bahwa pH air tambak di Kabupaten Pohuwato tergolong sesuai untuk budidaya di tambak. Walaupun telah dilaporkan sebelumnya, bahwa tambak di Kabupaten Pohuwato tergolong tanah sulfat masam, tetapi pada saat pengambilan contoh air, tambak lebih banyak terisi air dan kemungkinan tidak ada proses pembilasan dari pematang, sehingga menyebabkan $\mathrm{pH}$ air tambak masih tergolong netral.

Kandungan oksigen terlarut di tambak Kabupaten Pohuwato dapat mendukung budidaya di tambak. Batas oksigen terlarut untuk udang windu adalah 3- $10 \mathrm{mg} / \mathrm{L}$ dan optimum 4- $7 \mathrm{mg} / \mathrm{L}$ (Poernomo, 1988). Dengan kandungan oksigen terlarut $1-5 \mathrm{mg} / \mathrm{L}$ dalam waktu yang sangat Iama menyebabkan pertumbuhan udang windu menjadi lambat, kandungan oksigen terlarut $5 \mathrm{mg} / \mathrm{L}$ sampai jenuh adalah kondisi terbaik untuk pertumbuhan udang windu (Boyd, 1995). Ikan bandeng tumbuh dengan baik pada kisaran oksigen terlarut 3- 8 mg/ L (Ismail et al., 1993).

Senyawa $\mathrm{NO}_{3}$ (nitrat) adalah bentuk utama nitrogen di perairan alami dan merupakan nutrien utama bagi pertumbuhan tanaman dan alga. Nitrat tidak bersifat toksik terhadap organisme akuatik. Tidak seperti dengan $\mathrm{NO}_{3}$, $\mathrm{NO}_{2}$ (nitrit) beracun terhadap ikan, karena mengoksidasikan Fe di dalam hemoglobin. Dalam bentuk ini kemampuan darah untuk mengikat oksigen terlarut sangat merosot (Poernomo, 1988). Pada udang yang darahnya mengandung $\mathrm{Cu}$ (tembaga) (hemocyanin) mungkin terjadi oksidasi $\mathrm{Cu}$ oleh $\mathrm{NO}_{2}$ dan memberikan akibat yang sama seperti pada ikan (Smith \& Russo, 1975 dalam Poernomo, 1988). Kandungan $\mathrm{NO}_{2}$ yang lebih dari $0,05 \mathrm{mg} / \mathrm{L}$ dapat bersifat toksik bagi organisme akuatik yang sangat sensitif (Moore, 1991).

Seperti halnya dengan $\mathrm{NO}_{2}$, maka $\mathrm{NH}_{3}$ (amonia) juga bersifat racun bagi organisme akuatik. Kandungan $\mathrm{NH}_{3}$ air tambak di Kabupaten Pohuwato berkisar antara 0,0132 dan $3,4925 \mathrm{mg} / \mathrm{L}$ dengan rata- rata $0,5312 \mathrm{mg} /$ L; sedangkan di laut berkisar antara 0,0177 dan 0,3218 mg/L (Tabel 2). Kandungan $\mathrm{NH}_{3}$ 0,05- $2,0 \mathrm{mg} / \mathrm{L}$ sudah menghambat organisme akuatik pada umumnya. Apabila kandungan $\mathrm{NH}_{3}$ lebih dari 0,2 mg/L; perairan bersifat toksik bagi beberapa jenis ikan, kandungan amonia yang diperkenankan untuk budidaya udang windu adalah kurang dari $0,1 \mathrm{mg} / \mathrm{L}$ (Mustafa et al., 2007). Berdasarkan hasil analisis menunjukkan bahwa kandungan $\mathrm{NH}_{3}$ air di perairan pesisir Kabupaten Pohuwato tergolong tinggi, terutama di tambak.

Berdasarkan kandungan $\mathrm{PO}_{4}$, perairan diklasifikasikan menjadi tiga yaitu: perairan dengan kesuburan rendah yang memiliki kandungan $\mathrm{PO}_{4}$ 0- 0,02 mg/ L; perairan dengan tingkat kesuburan sedang yang memiliki kandungan $\mathrm{PO}_{4}$ 0,021-0,05 mg/ L; dan perairan dengan tingkat kesuburan tinggi yang memiliki kandungan $\mathrm{PO}_{4}$ 0,051- 0,10 mg/ L. Kandungan $\mathrm{PO}_{4}$ air tambak di Kabupaten Pohuwato 0,0030$4,5278 \mathrm{mg} / \mathrm{L}$ dengan rata- rata 0,2924 dan kandungan $\mathrm{PO}_{4}$ air di laut 0,006- 0,0798 mg/ L 
dengan rata- rata 0,0203 mg/L (Tabel 2). Hal ini menunjukkan bahwa kualitas air yang ditinjau dari kandungan $\mathrm{PO}_{4}$ tergolong pada tingkat kesuburan mulai dari yang rendah sampai yang tinggi.

Terlihat bahwa ada kemiripan pola pasang surut pada waktu dan tanggal yang sama antara data pengukuran dengan data Daftar Pasang Surut (Dinas Hidro- Oseanografi, 2011), sehingga data pasang surut dari Dinas HidroOseanografi (2011) dapat dijadikan acuan untuk tambak di Kabupaten Pohuwato (Gambar 1). Kisaran pasang surut di kawasan pesisir Kabupaten Pohuwato yang diolah dari data Daftar Pasang Surut (Dinas Hidro- Oseanografi, 2011) dari stasiun pasang surut terdekat yaitu sebesar 1,42 m. Kisaran pasang surut yang demikian, menunjukkan bahwa dengan elevasi tambak yang tepat, maka tambak dapat dikeringkan dan diisi air secara gravitasi, tanpa pematang utama dibuat lebih lebar dan tinggi untuk menahan tekanan air waktu pasang tinggi dan surut terendah.

\section{Iklim}

Salah satu faktor yang sangat berpengaruh terhadap budidaya di tambak adalah iklim, terutama curah hujan. Curah hujan dari tahun 2005 sampai 2009 di Kabupaten Pohuwato mencapai rata- rata $1.580 \mathrm{~mm} /$ tahun dengan distribusi bulanan seperti terlihat pada Gambar 2. Curah hujan di Kabupaten Pohuwato tergolong rendah untuk budidaya di tambak.
Curah hujan yang sangat sesuai untuk budidaya di tambak adalah $2.000-3.000 \mathrm{~mm} /$ tahun dengan 2- 3 bulan kering (Mustafa et al., 2011).

\section{Kesesuaian Lahan}

Sebagian besar tambak di Kabupaten Pohuwato dibangun di bekas Iahan hutan mangrove. Telah dilaporkan bahwa sekitar 2.000 ha hutan mangrove telah dialihfungsikan menjadi tambak yang berada di kawasan cagar alam Tanjung Panjang yang luasnya sekitar 4.000 ha (Anonim, 2011). Berdasarkan hasil analisis pasang surut dan Keputusan Presiden Nomor 32 Tahun 1990 tentang Pengelolaan Kawasan Lindung, maka jalur hijau di kawasan pesisir Kabupaten Pohuwato selebar $185 \mathrm{~m}$ dan sempadan sungai selebar $100 \mathrm{~m}$ di kiri kanan sungai besar serta $50 \mathrm{~m}$ di kiri kanan sungai kecil. Hal ini juga sesuai dengan Pasal 6 Peraturan Pemerintah Republik Indonesia Nomor 26 tahun 2008 tentang Rencana Tata Ruang Wilayah Nasional bahwa strategi untuk pencegahan dampak negatif kegiatan manusia yang dapat menimbulkan kerusakan lingkungan hidup yaitu melindungi kemampuan lingkungan hidup untuk menyerap zat, energi, dan atau komponen lain yang dibuang ke dalamnya.

Berdasarkan evaluasi kesesuaian lahan untuk tambak menunjukkan bahwa luas tambak yang ada di Kabupaten Pohuwato yaitu $5.368,2$ ha; di mana tidak ada tambak yang tergolong sangat sesuai (Kelas S1); 2.171,9

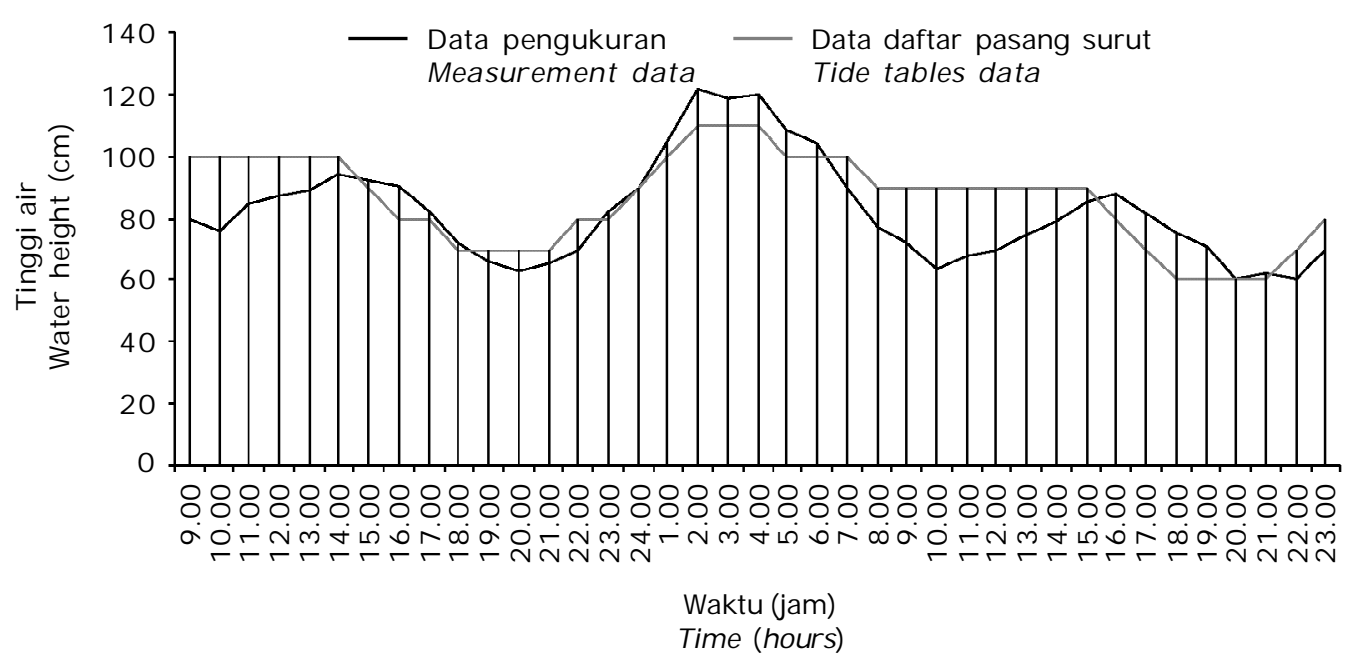

Gambar 1. Pasang surut di perairan pesisir Kabupaten Pohuwato Provinsi Gorontalo Figure 1. Tidal range in the coastal ar ea of Pohuwato Regency Gorontalo Province 


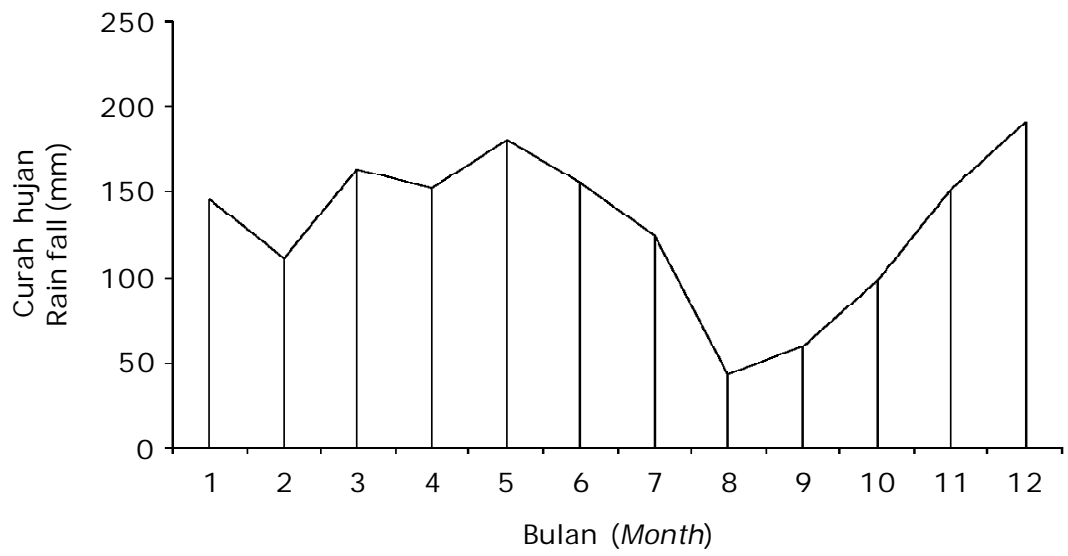

Gambar 2. Curah hujan bulanan di Kabupaten Pohuwato Provinsi Gorontalo

Figure 2. Monthly rain fall in Pohuwato Regency Gorontalo Province

ha yang tergolong cukup sesuai (Kelas S2); dan 3.196,3 ha yang tergolong kurang sesuai (Kelas S3). Setelah tambak yang berada di jalur hijau dan sempadan sungai dianggap sebagai faktor pembatas dan digolongkan sebagai tidak sesuai (Kelas N) maka luas tambak di Kabupaten Pohuwato yang tergolong cukup sesuai (Kelas S2) seluas 1.954,4 ha; yang tergolong kurang sesuai (Kelas S3) seluas $2.556,2 \mathrm{ha}$; dan yang tergolong tidak sesuai (Kelas N) seluas 857,6 ha (Tabel 3 dan Gambar 3).
Hasil kesesuaian lahan tersebut digolongkan kesesuaian lahan aktual sebab dinilai untuk kondisi saat ini berdasarkan karakteristik lahan sebelum lahan tersebut diberikan masukan-masukan yang diperlukan untuk mengatasi kendala atau faktor pembatas. Apabila usaha perbaikan dapat dilakukan, kelas kesesuaian lahan dapat naik satu tingkat pada golongan kesesuaian lahan potensial (Mustafa et al., 2011). Pada tambak yang tergolong cukup sesuai (Kelas S2) disarankan untuk melakukan budidaya udang secara tra-

Tabel 3. Luas setiap kesesuaian lahan aktual untuk budidaya di tambak di Kabupaten Pohuwato Provinsi Gorontalo

Table 3. Wide of each actual land suitability for brackishwater pond in Pohuwato Regency Gorontalo Province

\begin{tabular}{lrrrrr}
\hline \multirow{2}{*}{$\begin{array}{l}\text { Kecamatan } \\
\text { Subdistrict }\end{array}$} & \multicolumn{2}{c}{ Kesesuaian Iahan (Land suitability) (ha) } & \multirow{2}{*}{ Total } \\
\cline { 2 - 5 } & $\mathbf{S 1}$ & $\mathbf{S 2}$ & $\mathbf{5 3}$ & \multicolumn{1}{c}{$\mathbf{~ N}$} & \\
\hline Paguat & 0 & 2.5 & 174 & 11 & 187.5 \\
Marisa & 0 & 0 & 0 & 0 & 0 \\
Duhiadaa & 0 & 311 & 0 & 30.2 & 330.2 \\
Patilanggio & 0 & 142 & 0 & 45.2 & 187.6 \\
Randangan & 0 & $1,446.3$ & 79 & 129.8 & $1,655.1$ \\
Wanggarasi & 0 & 26.6 & 986.9 & 441.6 & $1,455.1$ \\
Lemito & 0 & 0 & 387.2 & 92.7 & 479.9 \\
Popayato Barat & 0 & 0 & 631.9 & 56.2 & 688.1 \\
Popayato & 0 & 0 & 297.1 & 46.6 & 343.7 \\
Popayato Timur & 0 & 25.6 & 0 & 15.4 & 41.0 \\
\hline \multicolumn{1}{c}{ Total } & $\mathbf{0}$ & $\mathbf{1 , 9 5 4 . 4}$ & $\mathbf{2 , 5 5 6 . 2}$ & $\mathbf{8 5 7 . 6}$ & $\mathbf{5 , 3 6 8 . 2}$ \\
\hline
\end{tabular}




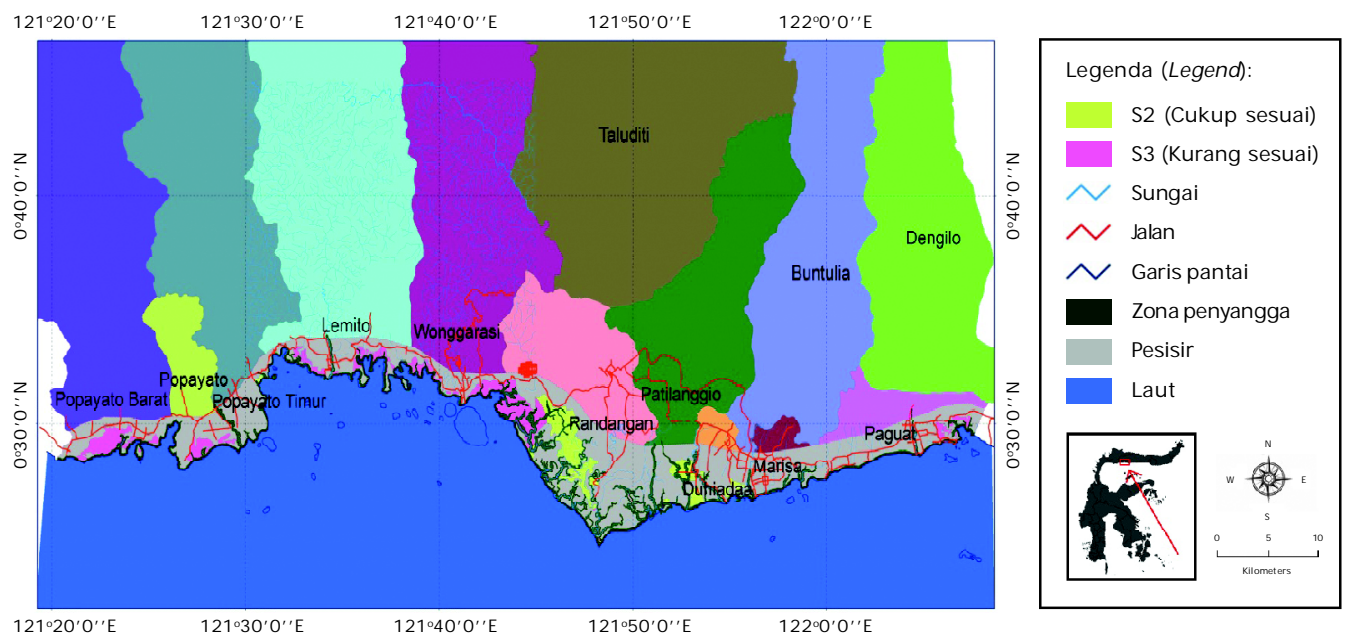

Gambar 3. Peta kesesuaian lahan aktual untuk budidaya di tambak Kabupaten Pohuwato Provinsi Gorontalo

Figure 3. Actual land suitabilty for brackishwater pond in Pohuwato Regency Gorontalo Province

disional atau tradisional plus, pada tambak yang tergolong kurang sesuai (Kelas S3) disarankan melakukan budidaya ikan bandeng atau polikultur ikan bandeng dengan rumput laut, sedangkan pada tambak yang tergolong tidak sesuai (Kelas N) sebaiknya dilakukan penanaman mangrove untuk rehabilitasi jalur hijau dan sempadan sungai.

Kandungan Fe yang relatif tinggi pada tanah sulfat masam di Kabupaten Pohuwato dapat dimanfaatkan untuk budidaya rumput laut (Gracilaria verrucosa). Tanaman termasuk rumput laut membutuhkan Fe sebagai penyusun sitokrom dan klorofil, serta berperan dalam sistem enzim dan transfer elektron pada proses fotosintesis (Effendi, 2003). Menurut Caliceti et al. (2002), Fe adalah logam yang dibutuhkan oleh alga paling besar dibandingkan dengan logam lainnya. Tanaman air dan alga bukan hanya mempunyai kemampuan dalam menyerap $\mathrm{Fe}$, tetapi juga dalam menyerap Al (Caliceti et al., 2002; Gosavi et al., 2004). Lebih Ianjut Gosavi et al. (2004) menyatakan bahwa alga dapat menyerap Fe dan Al tiga kali lipat dibandingkan dengan logam lainnya. Selain itu, tanaman air dan alga memiliki toleransi yang tinggi dibandingkan dengan ikan dan udang terhadap logam (Effendi, 2003). Telah dilaporkan sebelumnya bahwa Kabupaten Luwu, Luwu Utara, dan Luwu Timur, serta Kota Palopo di Provinsi Sulawesi Selatan memiliki kuantitas dan kualitas rumput laut terbaik di Indonesia, di mana daerah tersebut juga didominasi oleh tanah sulfat masam dengan kandungan Fe dan Al yang tinggi (Mustafa \& Sammut, 2010).

\section{Pengelolaan Lahan}

Sebagai faktor pembatas utama kesesuaian Iahan tambak di Kabupaten Pohuwato adalah potensi kemasaman tanah yang tinggi, kandungan bahan organik yang tinggi, dan tekstur tanah yang tergolong kasar. Pengelolaan lahan terutama tanah yang dapat dilakukan untuk menurunkan potensi kemasaman tanah adalah melalui remediasi baik berupa pengeringan, perendaman, dan pembilasan tanah maupun melalui pengapuran. Prinsip remediasi melalui pengeringan, perendaman, dan pembilasan tanah adalah pengeringan tanah untuk mengoksidasi pirit, perendaman untuk melarutkan dan menetral isir kemasaman atau menurunkan produksi kemasaman lanjut, dan pembilasan untuk membuang hasil oksidasi dan meminimumkan cadangan unsurunsur beracun dalam tanah (Mustafa $\&$ Sammut, 2007; Mustafa \& Rachmansyah, 2008). Bentuk lain remediasi berupa pengapuran dapat dilakukan untuk mengurangi unsur- unsur beracun dan unsur- unsur penyebab kemasaman tanah yang masih tersisa dalam tanah. Berdasarkan berat volume tanah (diprediksi dari kandungan bahan organik) dan nilai $\mathrm{S}_{\mathrm{POS}}$ tanah tambak, serta faktor konversi kapur, maka 
tambak di Kabupaten Pohuwato membutuhkan $\mathrm{CaCO}_{3}$ (kapur pertanian) berkisar antara 0,07 sampai 108,03 ton/ ha dengan rata- rata 30,38 ton/ha. Terlihat bahwa kuantitas kebutuhan kapur tergolong tinggi, namun demikian pengaplikasian dosis ini dapat memberikan pengaruh terhadap tanah untuk waktu yang cukup lama. Selain itu, dalam penentuan kebutuhan kapur berdasarkan nilai $\mathrm{S}_{\mathrm{pos}}$ tanah ini dapat tergolong cukup besar, sebab bahan penetral atau kapur diperhitungkan cukup untuk mengurangi potensial yang dapat merusak lingkungan (ASSMAC, 1998). Pada tanah tambak yang bukan tanah sulfat masam dengan $\mathrm{pH}$ tanah 5,0 pada tanah bertekstur berat, Boyd (1995) menyarankan penggunaan kapur pertanian sebanyak $14.320 \mathrm{~kg} /$ ha yang diaplikasikan setiap persiapan tambak.

Bahan organik yang sangat tinggi juga dapat menjadi faktor pembatas dalam kesesuaian lahan tambak di Kabupaten Pohuwato, terutama di Kecamatan Wanggarasi. Kandungan bahan organik yang tinggi dapat menyebabkan peningkatan populasi bakteri, $\mathrm{CO}_{2}$ (karbon dioksida), $\mathrm{H}_{2} \mathrm{~S}$ (hidrogen sulfida), dan $\mathrm{CH}_{4}$ (metan) yang dapat membahayakan kehidupan dan menghambat pertumbuhan organisme akuatik. Pada tanah dengan rasio $\mathrm{C}: \mathrm{N}$ tinggi, maka terjadi immobilisasi $\mathrm{N}$ oleh mikrobiologi untuk memenuhi kebutuhan metabolismenya. Penggunaan pupuk yang mengandung nitrogen seperti urea diharapkan dapat menurunkan rasio $\mathrm{C}: \mathrm{N}$ tanah yang juga dapat mempercepat proses penguraian bahan organik. Penguraian bahan organik dapat pula dipercepat melalui remediasi.

Tambak dengan tekstur tanah kasar sangat sulit untuk penumbuhan klekap yang merupakan makan penting bagi organisme yang dibudidayakan dengan teknologi tradisional. Tambak dengan tanah bertekstur kasar seperti pasir berlempung dan pasir memiliki tingkat porositas yang tinggi, sebagai akibatnya tambak tidak bisa menahan air. Tanah bertekstur kasar ini dapat menjadi faktor pembatas kesesuaian lahan tambak di Kabupaten Pohuwato, terutama untuk penerapan teknologi tradisional dan tradisional plus dan teknologi "perbaikan" tekstur tanah sangat sulit dan biaya sangat mahal. Upaya yang bisa dilakukan berupa pemasangan inti pematang berupa tanah liat yang disertai dengan pemasangan potongan bambu pada lereng pematang tambak dan pematang saluran air tambak. Pada tanah dasar yang teksturnya tergolong kasar dapat diberikan pupuk kandang terutama pada daerah yang rendah kandungan bahan organiknya seperti di Kecamatan Popayato Barat, Popayato, dan Popayato Timur, dengan harapan struktur tanah dasar tambak dapat lebih baik.

Persiapan tambak atau perbaikan tanah melalui remediasi sebaiknya dilakukan pada bulan Juli sampai Oktober, sebab pada saat itu curah hujan tergolong rendah. Dalam hal ini dapat mengefektifkan pengeringan tanah dasar tambak dan salinitas air yang tinggi sehingga proses remediasi dapat lebih baik.

\section{KESIMPULAN DAN SARAN}

Tambak di Kabupaten Pohuwato Provinsi Gorontalo memiliki karakteristik Iahan yang ditunjukkan oleh topografi yang memiliki bentuk wilayah yang relatif datar dan berelevasi rendah, tanah didominasi oleh tanah sulfat masam, kualitas air maupun pasang surut dapat mendukung usaha budidaya di tambak, dan curah hujan tergolong rendah. Dari luas tambak yang ada di Kabupaten Pohuwato yaitu 5.368,2 ha ternyata $1.954,4$ ha tergolong cukup sesuai (Kelas S2), 2.556,2 ha tergolong kurang sesuai (Kelas S3), dan 857,6 ha tergolong tidak sesuai (Kelas N). Sebagai faktor pembatas budidaya di tambak adalah kemasaman tanah yang tinggi, kandungan bahan organik tanah yang tinggi, dan tekstur yang tergolong kasar, sehingga pengelolaan lahan yang dilakukan adalah remediasi untuk menurunkan kemasaman tanah, pemberian pupuk yang mengandung nitrogen untuk mempercepat proses penguraian bahan organik, serta penggunaan tanah liat untuk mengurangi porositas pematang dan pemberian pupuk kandang untuk lokasi yang rendah kandungan bahan organiknya untuk memperbaiki struktur tanah dasar tambak. Sistem dan teknologi budidaya yang disarankan adalah monokultur udang dengan teknologi tradisional dan tradisional plus untuk tambak yang tergolong cukup sesuai (Kelas S2) dan monokultur ikan bandeng atau polikultur ikan bandeng dan rumput laut dengan teknologi tradisional untuk tambak yang tergolong kurang sesuai (Kelas S3).

\section{UCAPAN TERIMA KASIH}

Diucapkan terima kasih kepada Ilham dan Kamariah atas bantuannya dalam pengambilan dan pengukuran contoh tanah dan air di lapangan. Juga diucapkan terima kasih kepada 
Kamariah, Rosiana Sabang, dan Rahmiyah atas bantuannya dalam analisis kualitas tanah di laboratorium. Ucapan terima kasih juga disampaikan kepada Sutrisyani, St. Rohani, dan Kurnia atas analisis kualitas air di laboratorium. Kepada staf Dinas Kelautan dan Perikanan Kabupaten Pohuwato juga diucapkan banyak terima kasih atas bantuannya selama di lapangan.

\section{DAFTAR ACUAN}

Agus, F., Yusrial, \& Sutono. 2006. Penetapan tekstur tanah. Dalam Kurnia, U., Agus, F. Adimihardja, A., \& Dariah, A. (Eds.), Sifat fisik tanah dan metode analisisnya. Balai Besar Penelitian dan Pengembangan Sumberdaya Lahan Pertanian, Bogor, hlm. 43- 62.

Ahern, C.R. \& Blunden, B. 1998. Designing a soil sampling and analysis program. In Ahern, C.R., Blunden, B., \& Stone, Y. (Eds.), Acid sulfatesoils laboratory methods guidelines. Acid Sulfate Soil Management Advisory Committee, Wollongbar, NSW, p. 2.12.6.

Ahern, C.R. \& McElnea, A.E. 2004. Calculated sulfur parameters. In Acid sulfate soils laboratory methods guidelines. Queensland Department of Natural Resources, Mines, and Energy, Indooroopilly, Queensland, p. B11-1-B11-2.

Ahern, C.R., McElnea, A., \& Baker, D.E. 1998a. Peroxide oxidation combined acidity and sulfate. In Ahern, C.R., Blunden, B. , \& Stone, Y. (Eds.), Acid sulfate soils labor atory methods guidelines. Acid Sulfate Soil Management Advisory Committee, Wollongbar, NSW, p. 4.1-4.17.

Ahern, C.R., McElnea, A., \& Baker, D.E. 1998b. Total oxidisable sulfur. In Ahern, C.R., Blunden, B., \& Stone, Y. (Eds.), Acid sulfate soils laboratory methods guidelines. Acid Sulfate Soil Management Advisory Committee, Wollongbar, NSW, p. 5.1- 5.7.

Ahern, C.R. \& Rayment, G.E. 1998. Codes for acid sulfate soils analytical methods. In Ahern, C.R., Blunden, B., \& Stone, Y. (Eds.), Acid sulfate soils laboratory methods guidelines. Acid Sulfate Soil Management Advisory Committee, Wollongbar, NSW, p. 3.13.5.

Anonim. 2011. Pansus mangrove target bulan depan. Gorontalo Post, Sabtu, 28 Mei 2011, hlm. 2.

Anonymous. 1991. Mariculture of seaweeds.
In Shokita, S., Kakaz, K., Tomori, A., \& Toma, T. (Eds.), Aquaculture in tropical areas. Midori Shobo Co., Ltd., Tokyo, p. 31- 95.

APHA (American Public Health Association). 2005. Standard methods for examination of water and wastewater. APHA- AWWA- WEF, Washington. DC, 1,185 pp.

ASSMAC (Acid Sulfate Soil Management Advisory Committee). 1998. Acid sulfate soil management guidelines. In Ahern, C.R. Blunden, B., \& Stone, Y. (Eds.), Acid sulfate soils laboratory methods guidelines. Acid Sulfate Soil Management Advisory Committee, Wollongbar, NSW, p. III.1-28.

Bose, A.N., Ghosh, S.N., Yang, C.T., \& Mitra, A. 1991. Coastal aquaculture engineering. Oxford \& IBH Publishing Co. Pvt. Ltd., New Delhi, $365 \mathrm{pp}$.

Boyd, C.E. 1995. Bottom soils, sediment, and pond aquaculture. Chapman and Hall, New York, $348 \mathrm{pp}$.

Boyd, C.E. 2008. Pond bottom soil analyses. Global Aquaculture Advocate, September/ October: 91- 92.

Boyd, C.E., Wood, C.W., \& Thunjai, T. 2002a. Aquaculture pond bottom soil quality management. Pond Dynamics/ Aquaculture Collaborative Research Support Program Oregon State University, Corvallis, Oregon, $41 \mathrm{pp}$.

Boyd, C.E., Wood, C.W., \& Thunjai, T. 2002b. Pond soil characteristics and dynamics of soil organic matter and nutrients. In McElwee, K., Lewis, K., Nidiffer, M., \& Buitrago, P. (Eds.), Nineteenth Annual Technical Report. Pond Dynamics/ Aquaculture CRSP, Oregon State University, Corvallis, Oregon, p. 1- 10.

Bray, W.A., Lawrence, A.L., \& Leung-Trujillo, J.R. 1994. The effect of salinity on growth and survival of Penaeus vannamei with observations on the interaction of IHHN virus and salinity. Aquaculture, 122: 133- 146.

Caliceti, M., Argese, E., Sfriso, A., \& Pavoni, B. 2002. Heavy metal contamination in the seaweeds of the Venice lagoon. Chemosphere, 47: 443- 454.

Chanratchakool, P., Turnbull, J.F., Funge- Smith, S., \& Limsuwan, C. 1995. Health management in shrimp ponds. Second edition. Aquatic Animal Health Research Institute, Department of Fisheries, Kasetsart University Campus, Bangkok, 111 pp.

Dinas Hidro- Oseanografi. 2011. Daftar pasang surut tahun 2011 Kepulauan Indonesia. 
Dinas Hidro- Oseanografi TNI AL, Jakarta, $679 \mathrm{hlm}$.

DKP (Dinas Kelautan dan Perikanan) Kabupaten Pohuwato. 2010. Laporan Tahunan Dinas Kelautan dan Perikanan Kabupaten Pohuwato Tahun 2010. Dinas Kelautan dan Perikanan Kabupaten Pohuwato, Marisa, 47 hlm.

Effendi, H. 2003. Telaah kualitas air bagi pengelolaan sumber daya dan lingkungan perairan. Penerbit Kanisius, Yogyakarta, $258 \mathrm{hlm}$.

FAO (Food and Agriculture Organization). 1985. Guidelines: land evaluation for irrigated agriculture. In FAO Soil Bulletin 55. Soil Resources Management and Conservation Service and Water Development Division, FAO, Rome, 231 pp.

Golez, N.V. \& Kyuma, K. 1997. Influence of pyrite oxidation and soil acidification on some essential nutrient elements. Aquacultural Engineering, 16: 107- 124.

Gosavi, K., Sammut, J., Gifford, S., \&Jankowski, J. 2004. Macroalgal biomonitors of trace metal contamination in acid sulfate soil aquaculture ponds. Science of the Total Environment, 324(1- 3): 25- 39.

Hossain, M.S. \& Das, N.G. 2010. GIS- based multi-criteria evaluation to land suitability modelling for giant prawn (Macrobrachium rosenbergii) farming in Companigonj Upazila of Noakhali, Bangladesh. Computers and Electronics in Agriculture, 70(1): 172- 186.

Hurtado- Ponce, A.Q. \&Umezaki, I. 1987. Growth rate studies of Gracilaria verrucosa (Gigartinales, Rhodophyta). Botanica Marina, 30: 223- 226.

Ilyas, S., Cholik, F., Poernomo, A., Ismail, W., Arifudin, R., Daulay, T., Ismail, A., Koesoemadinata, S., Rabegnatar, I N.S., Soepriyadi, H., Suharto, H.H., Azwar, ZI., \& Ekowardoyo, S. 1987. Petunjuk teknis bagi pengoperasian unit usaha pembesaran udang windu. Pusat Penelitian dan Pengembangan Perikanan, Jakarta, $100 \mathrm{hlm}$.

Ismail, A., Poernomo, A., Sunyoto, P., Wedjatmiko, Dharmadi, \&Budiman, R.A.I. 1993. Pedoman teknis usaha pembesaran ikan bandeng di Indonesia. Pusat Penelitian dan Pengembangan Perikanan, Jakarta, $73 \mathrm{hlm}$.

Karthik, M., Suri, J., Saharan, N., \& Biradar, R.S. 2005. Brackish water aquaculture site selection in Palghar Taluk, Thane district of Maharashtra, India, using the techniques of remote sensing and geographical information system. Aquacultural Engineering, 32:285- 302.

McElnea, A.E. \&Ahern, C.R. 2004a. KCl extractable $\mathrm{pH}\left(\mathrm{pH}_{\mathrm{KCI}}\right)$ and titratable actual acidity (TAA). In Acid sulfate soils laboratory methods guidelines. Queensland Department of Natural Resources, Mines and Energy, Indooroopilly, Queensland, p. B2- 1- B2- 3.

McElnea, A.E. \& Ahern, C.R. 2004b. Peroxide $\mathrm{pH}\left(\mathrm{pH}_{\mathrm{ox}}\right)$, titratable peroxide acidity (TPA) and excess acid neutralising capacity $\left(\mathrm{ANC}_{\mathrm{E}}\right.$ ). In Acid sulfate soils laboratory methods guidelines. Queensland Department of Natural Resources, Mines and Energy, Indooroopilly, Queensland, p. B3- 1- B3- 7.

McElnea, A.E. \&Ahern, C.R. 2004c. Sulfur- peroxide oxidation method. In Acid sulfate soils laboratory methods guidelines. Queensland Department of Natural Resources, Mines and Energy, Indooroopilly, Queensland, p. B7-1- B7- 2.

McElnea, A.E. \& Ahern, C.R. 2004d. Sulfur 1M $\mathrm{KCl}$ extraction $\left(\mathrm{S}_{\mathrm{KC}}\right)$. In Acid sulfate soils laboratory methods guidelines. Queensland Department of Natural Resources, Mines and Energy, Indooroopilly, Queensland, p. B8- 1- B8- 2.

Moore, J.W. 1991. Inorganic contaminants of surface water. Springer- Verlag, New York, $334 \mathrm{pp}$.

Mustafa, A. 2011. Teknologi pendayagunaan tanah sulfat masam untuk akuakultur berkelanjutan. Orasi Pengukuhan Profesor Riset Bidang Akukultur, Jakarta, 28 November 2011. Badan Penelitian dan Pengembangan Kelautan dan Perikanan, Jakarta, 97 hlm.

Mustafa, A. \& Rachmansyah. 2008. Kebijakan dalam pemanfaatan tanah sulfat masam untuk budidaya tambak. Dalam Sudradjat, A., Rusastra, I W., \& Budiharsono, S. (Eds.), Analisis kebijakan pembangunan perikanan budidaya. Pusat Riset Perikanan Budidaya, Jakarta, hlm. 1- 11.

Mustafa, A., Rachmansyah, \& Hanafi, A. 2007. Kelayakan lahan untuk budi daya perikanan pesisir. Dalam Susilo, D.S.I., Wiadnyana, N.N., Wijayanti, E., Basmal, J., Asnawi, Supangat, A., Hanggono, A., \& Insan, I. (Eds.), Prosiding Simposium Nasional Hasil Riset Kelautan dan Perikanan Tahun 2007. Badan Riset Perikanan Budidaya, Jakarta, hlm. 141- 159.

Mustafa, A., Radiarta I N., \& Rachmansyah. 2011. 
Profil dan kesesuaian lahan akuakultur mendukung minapolitan. Diedit: Sudradjat, A. Swakarya, Jakarta, $91 \mathrm{hlm}$.

Mustafa, A. \& Sammut, J. 2007. Effect of different remediation techniques and dosages of phosphorus fertilizer on soil quality and klekap production in acid sulfate soil- affected aquaculture ponds. Indonesian Aquaculture Journal, 2(2): 141- 157.

Mustafa, A. \& Sammut, J. 2010. Dominant factors effecting seaweed (Gracilaria verrucosa) production in acid sulfate soilsaffected ponds of Luwu Regency, Indonesia. Indonesian Aquaculture Journal, 5(2): 147- 162.

Mustafa, A., Sapo, I., Hasnawi, \& Sammut, J. 2007. Hubungan antara faktor kondisi lingkungan dan produktivitas tambak untuk penajaman kriteria kelayakan Iahan: 1 . Kualitas air. J. Ris. Akuakultur, 2(3): 289- 302.

Parsons, T.R., Maita, Y., \& Lalli, C.M. 1989. A manual of chemical and biological methods for seawater analysis. Pergamon Press, Oxford, $173 \mathrm{pp}$.

Pérez, O.M., Ross, L.G., Telfer, T.C., \& del Campo Barquin, L.M. 2003. Water quality requirements for marine fish cage site selection in Tenerife (Canary Islands): predictive modelling and analysis using GIS. Aquaculture, 224: 51- 68.
Poernomo, A. 1988. Pembuatan tambak udang di Indonesia. Seri Pengembangan No. 7. Balai Penelitian Budidaya Pantai, Maros, 30 hlm.

Ponce- Palatox, J., Martinez- Palacios, C.A., \& Ross, L.G. 1997. The effect of salinity and temperature on the growth and survival rates of juvenile white shrimp, Penaeus vannamei, Boone, 1931. Aquaculture, 157: 107- 115.

Rossiter, D.G. 1996. A theoretical framework for land evaluation. Geoderma, 72: 165202.

Sulaeman, Suparto, \& Eviati. 2005. Petunjuk teknis analisis kimia tanah, tanaman, air, dan pupuk. Diedit: Prasetyo, B.H., Santoso, D., \& Widowati, L.R. Balai Penelitian Tanah, Bogor, $136 \mathrm{hlm}$.

Swingle, H.S. 1968. Standardization of chemical analysis for waters and pond muds. FAO Fisheries Report, 44(4): 397- 406.

van Dieven, C.A., van Keulen, H., Wolf, J., \& Berkhout, J.A.A. 1991. Land evaluation: from intuition to quantification. In Stewart, B.A. (Ed.), Advances in soil science. Springer, New York, p. 139- 204.

Young, A. 1987. Distinctive features of land use planning for agriforestry. Soil Survey and Land Evaluation, 7: 133- 140. 